referring to either political or economic aspects of development, he makes the obvious assumption that mankind should be the master and not the slave of its own social and economic systems.

Coming from a world traveller, we have timely reminders of the importance of communications and of scale so difficult to judge in small countries such as Britain-five times as far across mainland Canada and twice as far from Bom. bay to Calcutta as from John o'Groats to Land's End.

Seeing the Duke's interest in youth, it is not surprising that he is far from happy regarding the adequacy of higher education in technical fields. The appeal for forward thinking is well timed and, like every other aspects of life brought into this stimulating address, merits the closest attention.

L. Dudley Stamp

\title{
THE U.S. ACADEMY OF SCIENCES OFFICERS, MEDAL AWARDS AND NEW MEMBERS
}

$\mathrm{D}^{\mathrm{n}}$ R. J. A. STRATTON, president of Massachusetts Institute of Technology, has been elected to a four-year term as vice-president of the U.S. National Academy of Sciences. Dr. G. B. Kistiakowsky, Abbott and James Lawrence professor of chemistry, Harvard University, and Dr. Kenneth B. Raper, professor of bacteriology and botany, University of Wisconsin, have been appointed members of Council for a term of three years.

The following medal awards have been made: the Henry Draper Medal, for original investigation in astronomical physics, to Dr. Martin Schwarzschild, Princeton University Observatory; the Daniel Giraud Elliot Medal, for meritorious work in zoology or palæontology published each year, to Philip J. Darlington, jun., Museum of Comparative Zoology, Harvard University; the Kimber Genetics Medal, for achievement in the science of genetics, to Prof. J. B. S. Haldane, (recently) Indian Statistical Institute, Calcutta; the Jessie Stevenson Kovalenko Medal, for contributions to medical science, to Dr. K. F. Meyer, George Williams Hooper Foundation, University of California; the Mary Clark Thompson Medal, for services to geology and palæontology, to Dr. Norman D. Newell, American Museum of Natural History; the James Craig Watson Medal, for noteworthy discoveries or research in astronomy, to Prof. Otto Heckmann, Hamburg-Bergedorf Observatory.

The following new members have been elected: Prof. D. I. Arnon, professor of plant physiology, University of California; Dr. W. O. Baker, vicepresident in charge of research, Bell Telephone Laboratories; Prof. S. Benzer, professor of biophysics, Purdue University; Dr. H. A. Borthwick, principal plant physiologist, Agricultural Research Service, U.S. Department of Agriculture; Prof. R. H. Burris, professor of biochemistry, University of Wisconsin; Prof. Shiing-Shen Chern, professor of mathematics, University of California at Berkeley; Dr. P. E. Cloud, jun., chief, Paleontology and Stratigraphy Branch, U.S. Geological Survey; Prof. J. H. Comroe, jun., director of the Cardiovascular Research Institute and professor of physiology,
University of California Medical Center; Prof. D. J. Cram, professor of chemistry, University of California; Prof. J. F. Crow, professor of zoology and genetics, University of Wisconsin; Dr. L. S. Darken, associate director, research laboratory, United States Steel Corporation; Prof. C. Djerassi, professor of chemistry, Stanford University; Prof. W. Von Eggers Doering, professor of chemistry, Yale University; Prof. R. Dulbecco, professor of biology, California Institute of Technology; Prof. A. I. Hallowell, professor of anthropology, University of Pennsylvania; Prof. B. L. Horecker, professor of microbiology, New York University College of Medicine; Prof. R. D. Hotchkiss, member, and professor of cellular physiology, Rockefeller Institute; Dr. Libbie H. Hyman, research associate, American Museum of Natural History; Prof. M. G. Inghram, professor of physies, University of Chicago; Prof. W. N. Lipscomb, jun., professor of chemistry, Harvard University; Dr. H. F. Mark, director, Polymer Research Institute, Polytechnic Institute of Brooklyn; Prof. H. Neurath, professor of biochemistry, University of Washington; Prof. G. E. Palade, member, and professor of cytology, Rockefeller Institute; Prof. R. V. Pound, professor of physics, Harvard University; Prof. L. A. Riggs, professor of physiological psychology, Brown University; Dr. R. B. Roberts, chairman, Biophysics Section, Department of Terrestrial Magnetism, Carnegie Institution of Washington; Prof. Per F. Scholander, professor of physiology, Scripps Institution of Oceanography; Dr. C. D. Shane, astronomer, Lick Observatory; Prof. D. C. Spencer, professor of mathematics, Princeton University; Mr. H. M. Stommel, research associate in physical oceanography, Woods Hole Oceanographic Institution; Prof. Leo Szilard, professor of biophysics, University of Chicago; Prof. J. W. Tukey, professor of mathematics, Princeton University; Prof. F. T. Wall, research professor of physical chemistry, University of Illinois; Dr. A. M. Weinberg, director, Oak Ridge National Laboratory; Prof. J. H. Williams, professor of physics, University of Minnesota.

\section{OBITUARIES}

\section{Sir William Savage}

THe death of Sir William Savage in his eightyninth year on April 6,1961, means the passing of the last survivor of that distinguished company of medical officers of health who contributed so largely to the progress of public health in the late nineteenth and early part of the present century.

William George Savage, the son of John H. Savage, was born in Jamaica in 1872. He was educated privately, at University College, London, and University College Hospital. He took the B.Sc.(Lond.) 
in 1894, the M.B.Lond. with honours in medicine and the gold medal in forensic medicine in 1896, the diploma in public health in 1897 and the M.D.(Lond.) in 1898. After a resident post at the Royal Sussex Hospital, he became assistant professor of pathology in University College, London. From $1900-03$ he was lecturer in pathology and public health at University College, Cardiff, and during 1903 09 medical officer of health and public analyst, Borough of Colchester. In 1909 he was appointed the first county medical officer of Somerset. Here he did the work that was to make him famous.

Savage was remarkable in that he continued to pursue bacteriological researches which gave him an international reputation, and at the same time administered the public health of his county with conspicuous success.

The organisms present in food poisoning early engaged Savage's attention, and he did research work for the Medical Research Council, partly in collaboration with Bruce White, into the serology of the Salmonella groups and their relation to food poisoning (M.R.C. Reports, Nos. 91 and 92, 1925). He also showed that domestic animals and vermin were the main reservoirs of these organisms. He made further fundamental studies into food poisoning. In 1940, in a discussion at the Royal Society of Medicine, he gave an account of some original work on Salmonella dublin, pointing out that it was responsible for human infection in a number of cases; and as late as 1956 he published a paper with evidence on problems of Salmonella food poisoning, and directed attention to the marked increase of food poisoning in Great Britain since the end of the Second World War (Brit. Med. J., ii, 317; 1956).

Savage strongly advocated the pasteurization of milk; he wrote a report on milk and the public health in 1912, and published the following books: The Bacteriological Examination of Food and Water (1906), Rural Housing (1915), Food and the Public Health (1919) and Food Poisoning and Food Infections (1920). $\mathrm{He}$ was the author of a number of special reports to the Local Government Board, of papers on the prevention of human tuberculosis of bovine origin, on canned foods in relation to health, and on many other scientific subjects, the majority of which were based on his special investigations. He was Milroy Lecturer and Mitchell Lecturer at the Royal College of Physicians, president of the Society of Medical Officers of Health in 1935, examiner in public health for the Universities of London, Wales and Bristol, and received a knighthood for his distinguished services in 1938; in the same year the honorary degree of M.D.(Bristol) was conferred on him.

In 1937, Savage retired from the post of county medical officer but returned to assist in public health work in Somerset during the Second World War. Thereafter he did important work as chairman of the Ministry of Food's Catering Trade Working Party, while his advice and wisdom continued to be sought by other Government departments and public health bodies.

Savage was a strong man both physically and mentally. His interests were many. He played golf and lawn tennis up to an advanced age, was a daring swimmer and a keen gardener. Interested also in history and archæology, in retirement at Winchester, he published an important book, entitled The Making of Our Towns, in 1952 based on extensive research, and had been president of the Somerset Archæological Society in 1945. He was a staunch friend, kind and generous to many. Sir William married Mary A. M. Wilson in 1900, and they had a son and daughter. His son, Dr. S. W. Savage, is county medical officer of Warwickshire.

Arthur S. MacNalty

\section{Prof. Gideon Mer, O.B.E.}

Prof. Gideon Geronimo Mer, professor of epidemiology and director of the Malaria Research Station of the Hebrew University of Jerusalem, died on March 23, at the age of sixty-six, in Haifa. To malariologists all over the world he will be remem. bered for his work on the transmission of quartan malaria, for his method of determination of the age of mosquitoes - a technique now universally adopted in epidemiological studies of insect-borne diseases for a series of lucid papers on the bionomics of $A$. elutus, and for his studies of insecticides in recent years.

Prof. Mer was born in $\mathbf{1 8 9 4}$ in Poniewez, Lithuania (at that time part of Czarist Russia). Both his parents were physicians. After graduating from the Real Gymnasium he went, in 1912, to study medicine in Heidelberg. He remained there only two years. At the call of the idealistic youth movement he interrupted his studies and went to Palestine.

At the outbreak of the First World War he was exiled by the Turkish authorities to Egypt. He joined the British Forces, fought in Gallipoli and elsewhere, and later returned to Palestine with the armies of Allenby. After demobilization he directed the first reclamation works in the malaria-infested valleys of Ezdraelon and Jordan.

In 1924, after a brief return to Lithuania, and following a happy marriage, Mer went back to his medical studies. He chose Italy, for he wanted to gain first-hand experience from the famous Italian school of malariologists of Grassi, Marchiafava and Celli. He graduated with honours in 1928, and after spending a year in postgraduate studies at the schools of tropical medicine in Amsterdam and Paris, he returned in 1929 to Palestine to direct the Malaria Research Station of the Hebrew University at RoshPinah-Galilee, where he established free polyclinics for the Arab population of the region and soon was known as 'Hakim el Kabir', beloved and honoured by all.

Mer's research work was done under most difficult and exacting conditions. The experimental transmission of quartan malaria he carried out on himself and on his wife (volunteer Z. M.). The first trials on suppressive treatment of malaria with 'Chinoplasmin' were done in times of strife at the risk of his own life. During these pre-war years he also found time to serve as medical officer to British troops stationed in Galilee, to many of whom his home in the hills became well known.

With the outbreak of the Second World War, Mer volunteered, together with three of his assistants, to H.M. British Forces and commanded a malaria field laboratory in Iran, Iraq and Burma. He was made O.B.E. for his distinguished services and leadership.

After the War, he returned to Israel to use his newly acquired knowledge of modern insecticides for the reclamation of malarious areas. With the establishment of the State of Israel, he served with distinction on many health missions, as head of the Department of Preventive Medicine of the Armed. Forces during the war of independence, and for a brief period as director-general of the Medical Services.

MerR YoELI 